\title{
A new bioeconomic simulation tool for small scale fisheries based on game theory: GAMEFISTO model
}

\author{
Gorka Merino ${ }^{\mathrm{a}}$, Francesc Maynou and Antonio García-Olivares \\ Instituto de Ciencias del Mar (ICM-CSIC), Paseo Marítimo de la Barceloneta 37-49, 08003 Barcelona, Spain
}

Received 2 May 2007; Accepted 24 September 2007

\begin{abstract}
GAMEFISTO simulation model is presented as a tool to improve the small scale fisheries bioeconomic simulation techniques. The main novelty of the current model is the implementation of game theoretic techniques for forecasting the fishing effort trends and consequently, the fish population levels and the economic outcome, including landings, income and net profits. The model assigns individual fishing strategies to individual vessels according to their technical characteristics. The fishermen within a fishing fleet exploiting a single stock are assumed to be the decision agents, who share not only a fish population (modelled through stock externality) but also a market, through an offer-demand function (market externality). Mediterranean fisheries need to be analysed at vessel level due to the heterogeneity of its fishing fleets. A ten year simulation on red shrimp, Aristeus antennatus, is presented as an application of the presented GAMEFISTO model.
\end{abstract}

Key words: Game theory / Stochastic simulation / Bioeconomic model / Mediterranean fisheries / Aristeus antennatus

Résumé - Un nouvel outil de simulation bioéconomique pour les pêches artisanales, basé sur la théorie des jeux : le modèle GAMEFISTO. Le modèle de simulation GAMEFISTO est présenté comme un outil pour améliorer les techniques de simulation bioéconomique des pêches artisanales. La nouveauté principale, par rapport au modèle courant, est l'insertion de techniques de la théorie des jeux pour prévoir les tendances de l'effort de pêche et par conséquent, les niveaux de populations de poissons et les coûts économiques, y compris les débarquements, les revenus et les profits nets. Le modèle attribue des stratégies individuelles de pêche à des navires en particulier selon leurs caractéristiques techniques. Les pêcheurs d'une flottille de pêche exploitant un seul stock sont considérés comme les agents de décision qui partagent non seulement une population de poissons (modélisée au niveau de l'externalité de stock) mais aussi un marché, au travers d'une fonction, celle de l'offre et de la demande (externalité de marché). Les pêches méditerranéennes ont besoin d'être analysées au niveau du navire de pêche dû à l'hétérogénéité de ses flottilles. Une simulation sur dix ans de la crevette rouge, Aristeus antennatus, est présentée en tant qu'application du modèle GAMEFISTO.

\section{Introduction}

Fishing activity can be considered as an economic activity relying on a natural living resource. Bioeconomic models attempt to establish functional relationships between the exploited natural resources and the economy they generate (Merino 2006).

Bioeconomic simulation techniques have recently been developed to simulate the whole process of stock dynamics, fishing activity, fishery assessment and management as an adaptive process (Grant et al. 1981; Isakson et al. 1982; Sparre and Willman 1993; Mardle and Pascoe 2002; Ulrich et al. 2001, 2002; Lleonart et al. 2003).

Bioeconomic models must be useful to (Sparre and Willman 1993) (i) explain quantitatively the observed

\footnotetext{
a Corresponding author: gmerino@icm.csic.es
}

bioeconomic patterns of a fishery, (ii) to identify and select policy measures to achieve social and economic objectives and (iii) determine the optimum application of the selected measures.

Game Theory is a formal tool to analyse strategic interactions among a finite number of agents involved in a fishery (Sumaila 1997; Sumaila 1999). Strategic interactions in fisheries are interpreted as how the harvest by one agent highly affects the fishing strategy of the other agents (Grønbæk 2000). Game theoretic models have been widely used in fisheries bioeconomics, such as equilibrium global models with symmetrical agents (Hannesson 1997), dynamic age structured models applied to fleet conflicts (Sumaila 1997), countries sharing migratory species (Arnason et al. 2001), international policy making (Munro 2006), fishing rights conflicts (Levhari and Mirman 1980), high sea fisheries (Kaitala and Lindroos 1998), or investigating benefits of cooperation and 
non cooperation in shared fisheries management (Hannesson 1995). Most of these cases are related to theoretical exercises to describe the effects of sharing a fishery. The main difference of the GAMEFISTO model is that Game Theory is used to model quantitatively an observed behaviour in Mediterraneantype fisheries.

The simulation model presented here assumes that the key factor to understand the evolution of the bioeconomic patterns of a fishery is the evolution of the fishing mortality. The fishing mortality applied to a population will determine its abundance, its landings and the selling price and consequently the income it generates and the costs needed to exploit it. It is known that fishing mortality is composed of two concepts. The first is related to the efficiency to catch a target species, catchability, and the other is related to the intensity in the use of such efficiency, the fishing effort. The fishing effort is applied by a finite number of exploiters and the model simulates their fishing intensity through a Game Theoretic algorithm. Once the fishing strategy or behaviour of each exploiter (fisher) is calculated, the total mortality applied to the exploited species is calculated.

The approach was first proposed to explain an observed behaviour in a red shrimp fishery (Merino 2006; Merino et al. 2007) and it makes the simulation tool valid to test alternative management strategies (AMS) other than fishing effort reductions to achieve equivalent reduction of fishing mortality to keep stocks at healthy (profitable) conditions.

The model offers a new perspective on the behaviour of fishermen, considering its rationality and also offers a perspective on the long and short term uses of a fishery.

\section{Material and methods}

The bioeconomic simulation model presented (GAMEs in MEditerranean FIsheries Simulation TOols) (Merino 2006) introduces an effort dynamics submodel based on game theory to reproduce fishermen's behaviour as its main novelty. The exploited resource is described with classical biomass surplus models and the economic submodel is based on a simple balance between gross revenues and the costs derived from the fishing activity.

The simulation is structured in three well differentiated frames: the resource box, the economic submodel and the decision box.

The interaction between the exploited populations and the economic outcome they generate is the main characteristic of the bioeconomic simulation models (Isakson et al. 1982; Sparre and Willman 1993; Lleonart et al. 1999; Ulrich et al. 1999; Lleonart et al. 2003) and it is modelled by means of the fishing mortality term. Fishing mortality is dependent on a catchability term and on fishing effort and described in our model as an endogenous variable.

The decision submodel simulates the effort strategy adopted by a single fisherman with a game theoretic approach. The average catchability coefficient is introduced as a parameter in the simulation and recalculated for each vessel by means of individual catch per unit of effort data (Merino 2006; Merino et al. 2007).

\subsection{The resource box}

The model considers the resource as a pool of marine species that can be commercialized. Those species considered by the user as target species are formulated as renewable resources, i.e., an explicit population dynamics model determines its abundance in the exploited system, following a biomass surplus production model (Schaefer 1954; Schaefer 1957) (Eq. (1)) and Pella's solution concept (Pella 1967) (Eq. (2)):

$\frac{\mathrm{d} B}{\mathrm{~d} t}=r B\left(1-\frac{B}{K}\right)-L=r B\left(1-\frac{B}{K}\right)-F B=r B\left(1-\frac{B}{K}\right)-q E B$.

Biomass dynamics of a target population $(B)$ is described by an intrinsic growth parameter $(r)$, a carrying capacity term $(K)$ and landings as a rate $(L)$. Note that landings are described by available biomass $(B)$ and fishing mortality $(F)$. The last is composed of an average catchability $(q)$ coefficient and total fishing effort $(E)$.

The solution for time $t+\delta$, where $\alpha_{t}=r-F_{t}$ and $\beta=r K^{-1}$ is the following:

$$
B_{t+\delta}=\frac{\alpha_{t} B_{t} e^{\alpha_{t} \delta}}{\alpha_{t}+\beta B_{t}\left(e^{\alpha_{t} \delta}-1\right)} .
$$

The catches of the selected species $s$ of a $v$ vessel from the $N$ vessel fleet are:

$$
L_{s, v, t}=\int_{t}^{t+\delta} F_{s, v, t} B_{s, t} \mathrm{~d} t=\frac{F_{s, v, t}}{\beta_{s}} \operatorname{Ln}\left[1-\frac{\beta_{s} B_{s, t}\left(1-e^{\alpha_{s, t} \delta}\right)}{\alpha_{s, t}}\right] .
$$

The fishing mortality applied by a single fisherman to a target species $(F)$ is formulated combining a catchability coefficient $(q)$ and a fishing effort level $(E)$.

$$
F_{v, t}=q_{v, t} E_{v, t} .
$$

Catchability coefficient is dynamic, evolves in time with a constant annual increase $\varphi$ (Lleonart et al. 2003; Merino 2006; Merino et al. 2007). The increase in catchability coefficient simulates a constant increase in vessels' technology and fishing power. Note that increase in technology has no finite limit as time tends to infinite. In contrast, imposing limits to vessels' technical improvements would imply parameterization problems to allocate current technology in relation to a maximum (reachable only when $t \rightarrow \infty$ ). The simulations' time horizon is recommended not to exceed 15-20 years for realistic results. The use of a constant increase catchability model tends to approach the observed increase in technology at short and mid term.

$$
q_{v, t}=q_{v, t 0}(1+\varphi)^{t}
$$

The secondary species are those present in the fishing gears mixed with the target species and are also accounted for by the model. Neither their population dynamics nor the ecological interactions between species are explicitly modelled, but their landings $(L S)$ are related to the landings of target species of each vessel through a linear relation (Eq. (6)):

$$
L S_{s, v, t}=\mu_{s}+v_{s} \cdot L_{s, v, t} .
$$


The parameters $\mu$ and $v$ are empirically estimated for each target species and are respectively, the catch of secondary species in absence of target species and the catch unit of secondary for each target species catch unit.

\subsection{The economic submodel}

The economic submodel describes the transformation of landings into net profits by each fisherman. The target species' landings become revenues through product price $(p)$ dynamics depending on the offer (total landings). Note that total landings are the sum of the landings of each fisherman $v$ of the $N$ vessel fleet:

$$
p_{s, t}\left(\sum_{v=1}^{N} L_{s, v, t}\right)=\lambda_{s}\left(\sum_{v=1}^{N} L_{s, v, t}\right)^{\omega_{s}} .
$$

$\lambda$ is the price if only one unit of product was landed by the whole fleet. $\omega$ is the price flexibility, which describes the modification of the price when modifying the offer. Note that price will decrease when landings are more abundant and consequently, $\omega<0$.

The gross revenues for each vessel including income from $S$ target species and related secondary species (secondary species price, $p s$ ) is the following:

$$
R_{v, t}=\sum_{s=1}^{S}\left(p_{s, t} \cdot L_{s, v, t}+p s_{S} \cdot L S_{s, v, t}\right) .
$$

The economic balance is computed substracting the total costs of each vessel from the revenues. The costs that GAMEFISTO accounts for are divided in four groups (based partially on Lleonart et al. 1999):

- Trade cost $(C 1)$. It includes fishermen association taxes and sale process or commercialization taxes. It is expressed as a percentage of the total revenues and this percentage is considered to be the same for the whole fleet $(c 1)$.

$$
C 1_{v, t}=c 1 \cdot R_{v, t} / 100
$$

- Daily cost (C2). It includes fuel costs, net mending, daily food expenses, ice and other daily costs excluding labour costs. It is expressed as a function of fishing effort and reflects the fleets' heterogeneity.

$$
C 2_{v, t}=c 2_{v} E_{v, t}
$$

- Labour cost (C3). The share (c3) corresponding to the crew in function of the money remaining after deducting the common trade and daily costs $(M M)$. The share is considered to be the same for every vessel in a fleet.

$$
\begin{gathered}
M M_{v, t}=R_{v, t}-C 1_{v, t}-C 2_{v, t} \\
C 3_{v, t}=c 3 \cdot M M_{v, t} .
\end{gathered}
$$

- Compulsory cost (C4). Harbour costs, license, insurance and yearly costs supposed to be constant and expressed at vessel level.

\subsection{The decision box}

The output of the economic submodel is the net profits at vessel level $\left(\pi_{v}\right)$.

$$
\pi_{v, t}=R_{v, t}-C 1_{v, t}-C 2_{v, t}-C 3_{v, t}-C 4_{v, t} .
$$

In the model, fishers determine their effort strategy based on their expected discounted profits over time. The net present value of profits of each vessel $\left(N P V_{v}\right)$ assuming a non-zero discount rate $(\delta)$ is given by:

$$
N P V_{v}=\int_{t=t_{0}}^{\tau} e^{-\delta t} \pi_{v, t}
$$

For the main working hypothesis in the present document, fishermen are proposed to be a finite number of non cooperative players sharing a common resource and market. In a finite time interval, each fisherman will strive to maximize its discounted profits knowing that the fish that is caught by the others will not be available to him (stock externality) (Oakerson 1992; Mesterton-Gibbons 1993; Grønbæk 2000) and that the selling price of his product will be a result of the total production (market externality).

This working hypothesis has been demonstrated in previous works (Merino 2006; Merino et al. 2007) to be a realistic approach to Mediterranean fisheries. It is used in the present document as a tool to forecast the individual effort strategies (number of fishing days) and as a consequence the fishing mortality applied to the exploited stocks.

The vessels heterogeneity is expressed through the individual catchability coefficients $\left(q_{v}\right)$ and the individual daily $\left(C 2_{v}\right)$ and compulsory $\left(C 4_{v}\right)$ costs. The individual effort strategies will result from this heterogeneity. The fishery is modelled as a finite renewable resource shared by the $N$ asymmetric vessels within a fleet, hence the model considers the fishing system as an $N$-asymmetrical players game sharing a dynamic (multispecies) resource with a dynamic market. Its solution is considered next.

The solution concept searched in the decision box is Nash's solution for non cooperative games (Nash 1951; Luce and Raiffa 1989; Fudenberg and Tirole 1991; MestertonGibbons 1993; Merino 2006; Merino et al. 2007). The solution is proposed as a realistic approach to fishermen's behaviour that will direct the evolution of the whole fishery through the fishing mortality as a key factor. The solution to the individual effort strategies jointly with the individual catchability parameters will determine the fishing mortality on the targeted species and consequently its population dynamics, production and the economic outcome of its exploitation.

The effort strategies solution searched $\left(E_{1}^{*}, \ldots E_{i}^{*}, \ldots E_{N}^{*}\right)$ must satisfy the following condition:

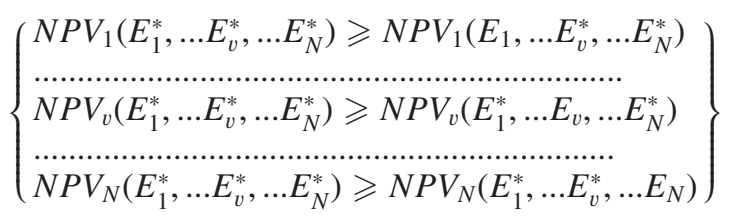

with the condition that $0 \leqslant E_{i} \leqslant E_{\max }$. 
Equation (15) is nothing but a non-cooperative scheme for an $N$-players game sharing a resource and its market. The system is solved with a successive approximation method to iteratively approximate solutions for the $N$ equilibrium equations. In other words, fishermen "play the game". Each fisherman evaluates its outcome with the effort strategies within 0 and $E_{\max }$. Only integer values were considered and the equilibria converged to the same Nash solution when fishermen to play first were alternated. Fishermen evaluated all the effort strategies and choose the one which results in the highest NPV value. Later on, the other fishermen decide theirs and as other players' effort changes, the first player re-evaluates its strategies and re-decides the most profitable. The iterations were alternatively run (each fisherman's decision) until Nash equilibrium was reached, i.e. an equilibrium where no player has a unilateral incentive to depart. The numeric results were unique for the case study and the robustness of the solution was validated (Merino 2006).

The effort strategy is constant during the simulation time, i.e. the game is quasi-static (Mesterton-Gibbons 1993; Sumaila 1998) and it characterizes agents as intensive, midintensity and occasional fishermen. In contrast, an uncertainty parameter (below) to each time effort decision will simulate deviations from the chosen strategy due to climate conditions or other non-economic factors.

\subsection{Time scale, initial conditions and uncertainty}

The bioeconomic loop is completed in a year time step after selecting a single effort strategy, constant in time, for each fisherman. The output variables, both biological and economic are displayed at a yearly scale. The model input is related to population and different level economic characteristics.

The stochastic simulation seeks to analyze the effects of uncertainty of one or several parameters (Lleonart et al. 1999; Lleonart et al. 2003; Merino 2006). The GAMEFISTO model assumes uncertainty on two processes, population dynamics and decision making.

The uncertainty on the surplus production models has widely been studied (Polacheck et al. 1993; Haddon 2001). The uncertainty observed on biomass models parameter estimation is focused on two aspects: a process error related to the population model and an observation error derived from the uncertainty of the available data that most of the times represents the main source of error in fishery science (Hilborn and Walters 1992). The process error is considered with a lognormal error structure at the moment of calculating catches, while the observation uncertainty is tackled with a normal distribution of observed error in the same catch equation (Eq. (16)). The parameter $m_{1}$ is the median slope relating estimated to observed catch, and $n_{1}$, is the standard deviation of the slopes. The observation error is considered additive and normally distributed, with a mean error $\left(\xi_{1}\right)$ and a standard deviation $\left(\sigma_{1}\right)$. A random normal distributed value is added to the calculated value. The uncertainty parameters should be based on observations. In each iteration of the stochastic simulations, the deterministic level of landings $\left(L_{s, v, t}\right)$ was replaced by a stochastic level of landings $\left(\tilde{L}_{s, v, t}\right)$.

$$
\tilde{L}_{s, v, t}=L_{s, v, t} \varepsilon_{1}+\eta_{1}
$$

where $\varepsilon_{1} \approx L N\left(\ln m_{1}, \ln n_{1}\right)$ and $\eta_{1} \approx N\left(\xi_{1}, \sigma_{1}\right)$. Note that $L N$ is a log-normal distribution.

The uncertainty in the decision making simulates the non controllable processes for the application of effort, i.e., environmental conditions that make impossible the activity or another exogenous (non strictly economic) variable that is not described by the model. Each value of temporal effort at vessel level is calculated assigning a lognormal multiplicative error and a normally distributed additive error (Eq. (17)). The parameter $m_{2}$ is the median slope relating estimated to observed effort, and $n_{2}$ its standard deviation. The observation error again is considered additive and normally distributed, with a mean error $\left(\xi_{2}\right)$ and a standard deviation $\left(\sigma_{2}\right)$. In each iteration of the stochastic simulations, the deterministic effort strategy resulting from Eq. (15) $\left(E_{v}\right)$ was replaced by a stochastic level of landings $\left(\tilde{E}_{v, t}\right)$. Note that the effort strategies may not remain exactly constant in time due to the stochastic term, recalculated each time step.

$$
\tilde{E}_{v, t}=E_{v} \cdot \varepsilon_{2}+\eta_{2}
$$

where $\varepsilon_{2} \approx L N\left(\ln m_{2}, \ln n_{2}\right)$ and $\eta_{2} \approx N\left(\xi_{2}, \sigma_{2}\right)$. Note that $L N$ is a log-normal distribution.

The simulation presented is performed attending to this uncertainty with a pool of iterations that are aggregated in mean and 5 and $95 \%$ quantile iterations.

\subsection{Application to the red shrimp fishery in Blanes (NW Mediterranean)}

Located in northern Catalonia, on the north-western Mediterranean, Blanes harbour was in 2004 the sixth port in term of revenues in Catalonia (Spain). The main target species of the local trawling fleet is the red shrimp, Aristeus antennatus (Risso 1816), representing almost $50 \%$ of its total income, which is the most important resource for the trawling fleets in the region (Sardá 2000; Sardá et al. 2003). Recent studies on population dynamics and assessments of Spanish Mediterranean stocks of $A$. antennatus showed that this species is slightly overexploited (Carbonell et al. 1999; Carbonell et al. 2003; Sardá et al. 2003). The data series from 1997 to 2004 report annual landings fluctuating from around the 60 tons from 1997 to 2002 with a significant decline from 2002 to 2004.

The bottom-trawl fleet of Blanes is composed of twelve vessels that operate near the Blanes submarine canyon from 400 to 800 m depths (Demestre and Lleonart 1993; Demestre and Martin 1993; Sardá 1993; Bas et al. 2003; Sardá et al. 2003) targeting red shrimp and a pool of secondary species. Trawlers, as common in Mediterranean fisheries, are heterogeneous, both in their technical characteristics (catchability and costs of fishing) and in their fishing behaviour (effort applied into a target species).

The accessory species caught jointly with the red shrimp are: Norway lobster (Nephrops norvegicus), blue whiting (Micromesistius poutassou), hake (Merluccius merluccius), squid (Loligo vulgaris), greater forkbeard (Phycis blennoides) and angler (Lophius piscatorius), that represent almost $36 \%$ of the total revenues of the trawling fleet. The need to account for secondary species' revenues is characteristic of Mediterranean fisheries (Lleonart et al. 2003). 
Table 1. Parameters related to the target red shrimp (Merino 2006) and COCTEL (Sardá 2000).

\begin{tabular}{|c|c|c|c|c|}
\hline Parameter & Meaning & Process & Equation & Value \\
\hline$r$ & Intrinsic growth & $\begin{array}{l}\text { Population } \\
\text { dynamics }\end{array}$ & $1,2,3,4$ & 0.96 year $^{-1}$ \\
\hline$K$ & Carrying capacity & & $1,2,3,4$ & $327700 \mathrm{~kg}$ \\
\hline$q_{2004}$ & Average catchability & & $1,2,3,4$ & $5.9 \times 10^{-4}$ day $^{-1}$ \\
\hline$B_{2004}$ & Initial biomass & & $1,2,3,4$ & $47846 \mathrm{~kg}$ \\
\hline$\mu$ & $\begin{array}{l}\text { Secondary species per vessel } \\
\text { when no target is landed }\end{array}$ & Secondary species & 5 & $24732 \mathrm{~kg}$ \\
\hline $\begin{array}{c}v \\
\text { unit landed }\end{array}$ & Unit of secondary for target & & 5 & $2.96 \mathrm{~kg} \mathrm{~kg} \mathrm{target}^{-1}$ \\
\hline$\lambda$ & $\begin{array}{l}\text { Price if only one unit was } \\
\text { landed by the fleet }\end{array}$ & Price dynamics & 6 & $2974 € \mathrm{~kg}^{-1}$ \\
\hline$\omega$ & Flexibility & & 6 & -0.42 \\
\hline$p s$ & Secondary species price & & 7 & $5.09 € \mathrm{~kg}^{-1}$ \\
\hline
\end{tabular}

Table 2. Parameters related to trawlers of the Blanes fleet (Merino 2006) and COCTEL (Sardá 2000). Daily cost $\left(c 2_{v}\right)$ includes fuel costs, net mending, daily food expenses, ice and other daily costs. Compulsory cost $\left(C 4_{v}\right)$ includes harbour costs, license, insurance and yearly costs supposed to be constant.

\begin{tabular}{cccc}
\hline Vessel & $\begin{array}{c}\text { Catchability } \\
\left(q_{v}, 10^{-4} \text { day }^{-1}\right)\end{array}$ & $\begin{array}{c}\text { Daily cost } \\
\left(c 2_{v}, € \text { day }^{-1}\right)\end{array}$ & $\begin{array}{c}\text { Compulsory cost } \\
\left(C 4_{v}, € \text { year }^{-1}\right)\end{array}$ \\
\hline v-1 & 1.2 & 358.5 & 51860 \\
v-2 & 6.8 & 960.5 & 75080 \\
v-3 & 6.3 & 636.2 & 66815 \\
v-4 & 8.3 & 653.8 & 75080 \\
v-5 & 2.9 & 551.3 & 50335 \\
v-6 & 9.1 & 868.0 & 69487 \\
v-7 & 5.4 & 950.0 & 75080 \\
v-8 & 7.2 & 469.0 & 50900 \\
v-9 & 2.5 & 195.5 & 67571 \\
v-10 & 9.4 & 950.0 & 51137 \\
v-11 & 2.9 & 486.6 & 64719 \\
v-12 & 8.8 & 736.6 & 75080 \\
\hline
\end{tabular}

Trawlers operate with crews of four or five people, in addition to the owner who usually is also the skipper and who makes any decision in terms of fishing strategies. The effort decisions are represented as days at the sea, which has been reported an adequate unit for Mediterranean fisheries (Lleonart et al. 1999; Lleonart and Maynou 2003; Lleonart et al. 2003; Merino 2006; Merino et al. 2007).

Parameters related to the target species (red shrimp) are shown in Table 1.

Parameters related to vessels characteristics are shown in Table 2.

There are some parameters that are the same for the entire fleet, such as the trade costs, share to the owner, discount rate, the annual increase in catchability and the limit to their activity (Table 3).

Uncertainty was introduced in the simulation model with Eqs. (16) and (17) and their parameters are shown in Table 4.
Table 3. Parameters related to trawlers of the Blanes fleet, (Merino 2006) and COCTEL (Sardá 2000). Trade cost (c1) includes fishermen association taxes and sale process or commercialization taxes. Share (c3) is the corresponding percentage to the crew in function of the money remaining after deducting the common trade and daily cost.

\begin{tabular}{lc}
\hline Trade cost & $7 \%$ \\
(c1, \% Total Income) & \\
Share $(\mathrm{c} 3 \% \mathrm{MM})$ & $50 \%$ \\
$\begin{array}{l}\text { Discount rate }(\delta) \\
\text { Annual increase in catchability }\end{array}$ & $0.04(4 \%)$ \\
Limit to effort & $3 \%$ \\
(maximum days at sea) & 240 days \\
\hline
\end{tabular}

Table 4. Uncertainty parameters into catch and effort equations (Merino 2006).

\begin{tabular}{cccc}
\hline \multicolumn{4}{c}{ Catch Eq. (16) } \\
\hline$m_{1}$ & $n_{1}$ & $\xi_{1}$ & $\sigma_{1}$ \\
1.031 & 1 & -605.6 & 6209.2 \\
\hline \multicolumn{4}{c}{ Effort Eq. (17) } \\
\hline$m_{2}$ & $n_{2}$ & $\xi_{2}$ & $\sigma_{2}$ \\
0.662 & 1 & 15.2 & 35.1 \\
\hline
\end{tabular}

\section{Results}

The first result obtained by the GAMEFISTO simulation model is the vessel-level effort strategy that will determine the fishing mortality applied to the target population from 2004 to 2013 and the evolution of the economic indicators of each vessel (Table 5).

As it is easily observed, a group of vessels (v-1, v-2, v-5, $\mathrm{v}-7$ and $\mathrm{v}-11)$ is calculated to leave the activity, another group (v-3, v-6, v-10 and v-12) is calculated to fish with mid intensity and three vessels (v-4, v-8 and v-9) will be estimated to fish more intensely, near the day limit imposed by the administrations.

It is important to note that the GAMEFISTO model does not consider negative effort strategies and when the uncertainty introduced in the effort equation (Eq. (17)) leads to a negative value it will be recalculated. As a consequence of this and of the positive parameters $\xi_{2}$ and $\sigma_{2}$ the simulation will assign 


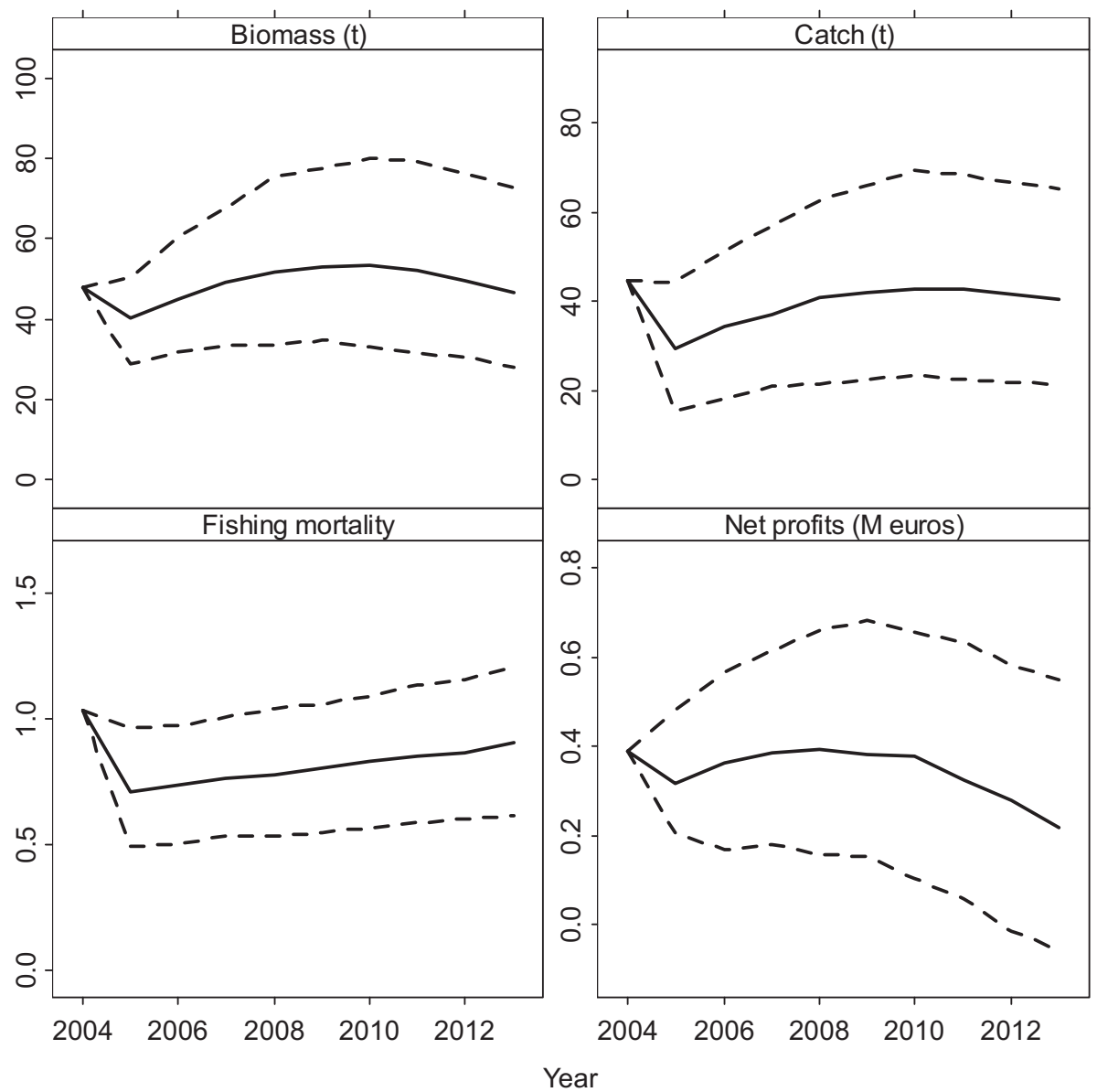

Fig. 1. Projections of the bioeconomic indicators of the Blanes red shrimp (Aristeus antennatus) fishery in Blanes (NW Mediterranean) with the GAMEFISTO model.

Table 5. Forecasted individual vessel's effort strategies.

\begin{tabular}{crr}
\hline Vessel & $\begin{array}{c}\text { Effort } \\
\text { (days at } \\
\text { sea })\end{array}$ & $\begin{array}{c}\text { Expected } \\
\text { discounted profits } \\
\left(10^{3} €\right)\end{array}$ \\
\hline v-1 & 0 & -10.02 \\
v-2 & 0 & -44.55 \\
v-3 & 155 & 243.72 \\
v-4 & 196 & 452.81 \\
v-5 & 0 & 34.32 \\
v-6 & 124 & 332.30 \\
v-7 & 0 & -139.83 \\
v-8 & 240 & 779.14 \\
v-9 & 240 & 65.51 \\
v-10 & 103 & 496.83 \\
v-11 & 0 & -55.19 \\
v-12 & 168 & 437.66 \\
\hline Total & 1226 & 2592.9 \\
\hline
\end{tabular}

positive low values of effort to vessels initially estimated to leave the red shrimp fishery. The initial total effort of 1226 will be increased in the simulation assigning low values to vessels initially estimated not to fish.
To sum up, the model classifies fishermen in low, mid and high effort intensity groups attending to their technical characteristics to exploit the studied target species.

The resulting fishing mortality, which is a sum of the product between each fishermen effort strategy and their respective catchability coefficients will determine the population abundance, the landings and net profits (Fig. 1).

Displayed projections indicate that population will be sustained at around 45-50 tons, representing 14-15\% of its carrying capacity, which means a significant overexploitation level. Landings are estimated to fluctuate around 40 tons, which represent a considerable reduction from the preceding decade, where they did around 60 tons. The observed high fishing mortality observed during 2004 (Merino 2006) is estimated to be slightly reduced. The profitability of the exploitation is simulated to be stabilized at around $0.4 \mathrm{M} €$ and seems to be declining on the long run.

GAMEFISTO model allows an economic analysis at vessel level but it was assumed as non relevant for the present document. 


\section{Discussion}

The results obtained for the case study must be analyzed considering some characteristics of Mediterranean fisheries. First is misreporting: there are indications that allow to assure that fishermen revenues are underestimated and probably costs overestimated (Merino 2006). As a consequence, vessels supposed to be obtaining negative benefits that should lead them to leave the activity are obtaining higher landings than the reported in the data series used for parameter estimation. The uncertainty algorithm in the effort equation (Eq. (17)) allows the correction of this phenomenon assigning low effort with a non-null probability to those vessels estimated to apply a null effort. On the other hand, fishermen may choose between two or three fishing grounds and may decideto apply no effort to red shrimp. Red shrimp is the most valuable target species but also the one caught in the farther grounds and the fishery that brings higher costs. As a consequence, vessels deciding not to apply an effort unit to red shrimp, will apply it to another target species. The model describes only the behaviour related to the red shrimp exploitation.

The projections of the bioeconomic indicators suggest that analyzing the red shrimp fishery as a shared resource, makes it possible to assure that the stock will not be overexploited to extinction, despite being heavily overfished. The model estimates a slight decrease in the fishing effort observed in 2003 and 2004 bringing a slight reduction of the mortality applied into the red shrimp population and total profits fluctuating around the 0.2 and $0.6 \mathrm{M} €$ with the mean trajectory stable at 0.4 .

The GAMEFISTO simulation seeks to approach to an observed reality of the bioeconomic indicators of a fishery through the fishing behaviour of the vessels operating it. It may be stated that a macro-observation is analyzed attending to a pool of micro-realities (Finlayson 1994). The response of fishermen at the time of decision making to a management scheme will determine the evolution of the exploited populations and the economic outcome of the activity.

The model analyzes these responses through Game Theoretic analysis, which represent its main novelty. It was initially conceived for Mediterranean fisheries and it is adequate to fisheries where vessel level analysis is needed and where boats present a significant technical heterogeneity, which is the case of many small-scale coastal fisheries. Based on that heterogeneity the model estimates some observed behaviour of choosing a fishing ground or staying at the port due to bioeconomic variables such as declines in the exploited populations' abundance, increase in fishing costs derived from changes in fuel price or other economic events. It also responds to the need to account for income from multispecific landings, very common in Mediterranean and tropical fisheries.

The model is based on the "shared resource" concept (Hardin 1968) and is formulated through two concepts such as "stock and market externalities" (Mesterton-Gibbons 1993; Grønbæk 2000) that relate individual behaviour to other fishermen strategies. Mathematically, equations are solved with Nash's solution concept for non cooperative players (Nash 1951; Mesterton-Gibbons 1993).

The model allows also to understand fishermen behaviour, which is leading many of the world's stocks into overfishing or collapse (Pauly et al. 2002; FAO 2004) as rational
(Camerer and Fehr 2006). Understanding the processes that direct the evolution of a system is highly necessary to estimate its future.

Moreover, the model allows to analyze the effects of some bioeconomic management actions such as removing subsidies, motivating the dismissal of boats, reducing the limits to effort, controlling the price formation of the selling product or the technical investments into the fishing units.

The GAMEFISTO model is also provided with two optimization algorithms. The first, it is constrained with a homogenous effort solution that maximizes the expected discounted profits imposing a homogeneous fishing behaviour, and the second, it chooses the vessels that will apply the effort leading the fishery near to the maximum economic yield.

GAMEFISTO departs from other multi-species bioeconomic simulation models (Placenti et al. 1995; Babcock and Pikitch 2000; Sparre 2001; Ulrich et al. 2002; Griffin 2003; Lleonart et al. 2003), essentially on its Game Theoretic algorithm. For Mediterranean fisheries, the only bioeconomic models available until now were the MEFISTO and MOSES simulation models, the first based on age structured populations and a decision box based on empirical rules and the second, based on equilibrium populations and effort allocation. The uncertainty included in the catch and effort equations represents another improvement that was already present in MEFISTO simulation model for Mediterranean fisheries (Lleonart et al. 2003).

Acknowledgements. Thanks to two anonymous referees for their constructive suggestions.

\section{References}

Arnason R., Magnusson G., Agnarsson S., 2001, The Norwegian Spring-spawning herring fishery: a stylised game model. Mar. Resour. Econ. 15, 293-319.

Babcock E.A, Pikitch E.K, 2000, A dynamic programming model of fishing strategy choice in a multispecies trawl fishery with trip limits. Can. J. Fish. Aquat. Sci. 57, 357-370.

Bas C, Maynou F., Sardá F., Lleonart J., 2003, Variacions Demogràfiques a les Poblacions d'espècies Demersals Explotades. Els Darrers Quaranta Anys a Blanes i Barcelona, Barcelona, Institut d'Estudis Catalans.

Camerer C.F., Fehr E., 2006, When does "economic man" dominate social behaviour? Science 311, 47-52.

Carbonell A., Bruno J., Gaza M., Fernández J.L., 2003, Stock assessment of the red shrimp (Aristeus antennatus) in the management unit 5. Balearic zone, Northern Spain. Working doc. No. 3 to the GFCM SAC Working Group on the assessment of demersal stocks.

Carbonell A., Carbonell M., Demestre M., Grau A., Montserrat S., 1999, The red shrimp Aristeus antennatus (Risso, 1816) fishery and biology in the Balearic islands, western Mediterranean. Fish. Res. 44, 1-13.

Demestre M., Lleonart J., 1993, Population dynamics of Aristeus antennatus (Decapoda: Dendrobranchiata) in the Northwestern Mediterranean. Sci. Mar. 57, 183-189.

Demestre M., Martin P., 1993, Optimum exploitation of a demersal resource in the western Mediterranean: the fishery of the deepwater shrimp Aristeus antennatus (Risso, 1816). Sci. Mar. 57, 175-182. 
ESRI, 2004, ArcGIS 9.0.

FAO, 2004, The State of World Fisheries and Aquaculture, Rome, Food and Agriculture Organization of the United Nations.

Finlayson A.C., 1994, Fishing for truth: A sociological analysis of northern cod stock assessments from 1977-1990. St. John's, Newfoundland, Canada. Memorial University of Newfoundland.

Fudenberg D., Tirole J., 1991, Game Theory, Cambridge, MIT Press.

Grant W.E., Isakson K.G., Griffin W.L., 1981, A general bioeconomic simulation model for annual-crop marine fisheries. Ecol. Model. $13,195-219$.

Griffin W.L., 2003, A General Bioeconomic Fisheries Simulation Model: Description, Calibration, Validation, and Application. Proc. $1^{\text {st }}$ North Am. Fish. Econ. Forum pp. 97-112.

Grønbæk L., 2000, Fishery Economics and Game Theory, Esberj, University of Southern Denmark.

Haddon M., 2001, Modelling and quantitative methods in fisheries, Boca Ratón, Florida, Chapman and Hall.

Hannesson R., 1995, Sequential fishing: cooperative and noncooperative equilibria. Nat. Res. Model. 9, 51-59.

Hannesson R., 1997, Fishing as a supergame. J. Environ. Econ. Manage. 32, 309-322.

Hardin G., 1968, The tragedy of the commons. Science 162, 12431248.

Hilborn R., Walters C.J., 1992, Quantitative Fisheries Stock Assessment: Choice, Dynamics and Uncertainty. London. Chapman and Hall.

Isakson K.G., Grant W.E., Griffin W.L., 1982, General Bioeconomic Fisheries Simulation Model: A detailed model documentation. J. Int. Soc. Ecol. Model. 4, 61-85.

Kaitala V.T., Lindroos M., 1998, Sharing the benefits of cooperation in high seas fisheries: A characteristic function game approach. Nat. Res. Model. 11, 275-299.

Levhari D., Mirman L.J., 1980, The great fish war: An example using a dynamic Cournot-Nash solution. Bell J. Econ. 11, 322-334.

Lleonart J., 1999, Precautionary approach and Mediterranean fisheries. Precautionary approaches to local fisheries and species introductions in the Mediterranean. CIESM Workshop.

Lleonart J., Maynou F., 2003, Fish stock assessments in the Mediterranean: state of the art. Sci. Mar. 67, 37-49.

Lleonart J., Maynou F., Franquesa R., 1999, A bioeconomic model for Mediterranean fisheries, the hake off Catalonia (western Mediterranean) as a case study. Fish. Econ. Newsl. 48, 1-16.

Lleonart J., Maynou F., Recasens L., Franquesa R., 2003, A bioeconomic model for Mediterranean fisheries, the hake off Catalonia (western Mediterranean) as a case study. Sci. Mar. 67, 337-351.

Luce R.D., Raiffa H., 1989, Games and Decisions. Introduction and Critical Survey, New York. John Wiley and Sons, Inc.

Mardle S., Pascoe S., 2002, Modelling the effects of trade-offs between long and short-term objectives in fisheries management. J. Environ. Manage. 65, 49-62.

Merino G., 2006, Simulation techniques for the bioeconomic analysis of Mediterranean fisheries. Game theory and effort dynamics. GAMEFISTO model, PhD thesis, Barcelona, Universitat Politécnica de Catalunya.

Merino G., Maynou F., García-Olivares A., 2007, Effort dynamics in a fisheries bioeconomic model: A vessel level approach through game theory, Sci. Mar. 71(3), 537-550.

Mesterton-Gibbons M., 1993, Game-Theoretic resource modeling. Nat. Res. Model. 7, 93-147.

Munro G.R., 2006, Game Theory and the development of resource management policy: The case of international fisheries. 6th meeting on game Theory and Practice Dedicated to Development, Natural Resources and the Environment, Zaragoza.

Nash J.F., 1951, Non-cooperative games. Ann. Math. 54, 286-295.

Oakerson R.J., 1992, Analyzing the commons: A framework. In: Bromley D.W. (Eds.) Making the commons work: Theory, practice and policy. San Francisco, ICS Press, pp. 41-59.

Pauly D., Christensen U.V., Guénette S., Pitcher T., Sumaila U.R., Walters C.J., Watson R., Zeller D., 2002, Toward sustainability in world fisheries. Nature 428, 689-695.

Pella J.J., 1967, A study of methods to estimate the Schaefer model parameters with special reference to the yellowfin tuna fishery in the eastern tropical Pacific ocean, Seattle. University of Washington.

Placenti V., Rizzo G., Spagnolo M., 1995, A Bio-Economic model for the Mediterranean Fisheries, Final report. Directorate General XIV Fisheries (MA-2.585), IREPA.

Polacheck T., Hilborn R., Punt A.E., 1993, Fitting surplus production models: Comparing methods and measuring uncertainty. Can. J. Fish. Aquat. Sci. 50, 2597-2607.

Sardá F., 1993, Bio-ecological aspects of the decapod crustacean fisheries in the Western Mediterranean. Aquat. Living Resour. 6, 299305.

Sardá F., 2000, Analysis of the Mediterranean (including North Africa) deep-sea shrimp fishery: evolution, catches, efforts and economics. DG XIV/97/0018. Final report.

Sardá F., Company J.B., Maynou F., 2003, Deep-sea Shrimp Aristeus antennatus Risso 1816 in the Catalan Sea, a review and perspectives. J. Northwest. Atl. Fish. Soc. 31, 127-136.

Schaefer M.B., 1954, Some aspects of the dynamics of populations important to the management of commercial marine fisheries. Bull. IATTC. 1, 27-56.

Schaefer M.B., 1957, A study of the dynamics of fishery for yellowfin tuna in the Eastern Tropical Pacific Ocean. Bull. IATTC. 2, 247285.

Sparre P.J., 2001, Simulation model for evaluation of effort and catch quota management regimes using the methodology of ICES. , Charlottenlund. Danish Institute for Fisheries Research.

Sparre P.J., Willman R., 1993, Software for bio-economic analysis of fisheries. BEAM 4. Analytical Bio-economic Simulation of Space-structured Multispecies and Multi-fleet Fisheries. Vol. 1. Description of the model. Computerized information series (Fisheries).

Sumaila U.R., 1997, Cooperative and non-cooperative exploitation of the Arcto-Norwegian cod stock. Environ. Res. Econ. 10, 147-165.

Sumaila U.R., 1998, Protected marine reserves as fisheries management tools: a bioeconomic analysis. Fish. Res. 37, 287-296.

Sumaila U.R., 1999, A review of game theoretic models of fishing. Mar. Policy 23, 1-10.

Ulrich C., Le Gallic B., Dunn M.R., 1999, Bioeconomic modelling of English Channel fisheries and their technical interactions: presentation of the simulation model BECHAMEL (BioEconomic CHAnnel ModEL). ICES CM 199/S:04.

Ulrich C., Gascuel D., Dunn M.R., Le Gallic B., Dintheer C., 2001, Estimation of technical interactions due to the competition for resource in a mixed-species fishery, and the typology of fleets and métiers in the English Channel, Aquat. Living Resour. 14, 267-281.

Ulrich C., Le Gallic B., Dunn M.R., Gascuel D., 2002, A multispecies, multi-fleet bioeconomic simulation model for the English Channel artisanal fisheries. Fish. Res. 58, 379-401. 